\title{
World-class education: A response to global challenges
}

\author{
Clementina Acedo
}

Published online: 21 September 2012

(C) UNESCO IBE 2012

The importance of world-class education is demonstrated in the remarkable amount of attention the concept-and its implications for major education reforms - are currently attracting around the world. In several countries national and local education reforms seek to create educational systems whose graduates can successfully participate in a global society and contribute to an expanding global economy. This importance is also reflected in the wide range of specific educational programs being created, the choices being made, and the new educational challenges that are emerging.

This special issue of Prospects critically examines the continued efforts to identify and analyze the possibilities and limitations of attempts to further refine measures of worldclass education. Further, it presents detailed case studies of the interpretations made by several countries and initiatives, such as South Korea, China, the state of Ohio in the United States, and the International Baccalaureate (IB), as they design and implement institutional responses to the evolving global challenges.

The authors contributing to this issue, guest-edited by Dr. Don Adams, point to the complexity of various definitions that the concept encompasses. They also single out a predominant definition, which equates a "world-class" educational system with students' excellent scores on international tests. In some countries, attaining world-class education has become a vigorous national policy. One might view the increasingly important international assessments as entrance examinations to the exclusive club of countries with such educational systems or see them as a set of supranational instruments for standardization. Thus, as Adams points out, important questions remain to be answered: Who is involved in advocating for testing to play a key role in constructing quality education? Whose voices are being heard? Whose are not? Whose discourse is it that results in particular standards, benchmarks, and indicators?

Susan Robertson notes that we could view world-class education as an education "[...] that is open-minded about, and open to, learning that engages with a range of world concerns". Instead, it has been viewed instrumentally. The foci become questions related to what world-class education involves, what path will lead to it, and who will benefit. She

C. Acedo $(\triangle)$

UNESCO IBE, P.O. Box 199, 1211 Geneva 20, Switzerland

e-mail: c.acedo@ibe.unesco.org 
suggests that questions should focus not on the demand but rather on "who is advancing the claim" and who stands to benefit from the claim. The answers to these questions may be useful to both universities and the larger societies they serve. Robertson further notes that the widely published rankings "take on a life of their own", which leads to "fragments of knowledge which parade as fractals".

Henry Levin argues persuasively that schools have a broader impact on societies and their economies than what is measured by PISA and other test scores. He accepts existing evidence that formal schooling influences school readiness, which contributes to achievement, and also that schools influence the development of other personality traits, skills and competencies which are determinants of both achievement and work productivity. However, he points out that by focusing attention exclusively on one dimension of educational outcomes-cognitive test scores-we are influencing the establishment of educational policies that are likely to undermine social and economic productivity. Further, Levin presents evidence that, compared to cognitive skills, the other, non-cognitive, skills and competencies may have even a greater long-term impact on wage levels and educational success.

Esther Gottlieb describes how the state of Ohio in the United States became deeply engaged in planning and developing a world-class system of education. The planning process included reviews of reform efforts by other US states and selected countries. She outlines the emerging plan for a statewide educational reform to redesign and improve schools from kindergarten through the twelfth grade. Ohio is preparing for a twenty-first century economy and society and is building the supporting knowledge and academic skills which are seen as crucial to attaining an active citizenship and competitive workforce.

In discussing the Chinese model of world-class universities, Jun Li thoroughly reviews definitions and benchmarks of quality and world-class institutions of higher education, both classical and contemporary, both Western and Eastern; this exposition provides a basis for understanding the unique Chinese model. He also examines the lively and extensive debate in China on world-class goals and decisions about reaching them. This model presents a good example of openness to learning from the past and from other countries, and Li shows us variations of the model in three case studies of contemporary Chinese universities.

Chong Jae Lee, Yong Kim, and Soo-yong Byun focus primarily on the development of the Korean education system since the end of the Korean War in 1953. In a few decades, the new Republic of Korea built a robust economy and an advanced education system. The commitment to a sequential pattern of educational growth brought rapid changes in the average number of years Korean children and youth spend in schools; this number rose to 10.6 years by 2001 . Lee and his colleagues trace the development and growth of the education system, as the nation rapidly built a system providing high quality education for all and a competitive globalized economy.

Ian Hill, in describing the origins and development of the IB programmes, emphasizes the importance of UNESCO's focus on such issues as education for peace and intercultural understanding. He observes: "A world-class education is cognizant of globalization and the need for an education whose perspective extends across national frontiers". Thus, in addition to knowledge, skills and attitudes, "world-class" can be taken to mean embracing international ideals, learning international languages, and attaining a comprehensive world view.

Acknowledgments My special thanks to Simona Popa for her contribution to the writing of this editorial. 